\title{
PENGEMBANGAN KARAKTER MELALUI \\ PENDIDIKAN AGAMA ISLAM
}

\author{
Feiby Ismail \\ STAIN Manado \\ feibyismail@yahoo.com
}

\begin{abstract}
Abstrak
Pendidikan tidak hanya merupakan transfer informasi, ilmu pengetahuan dan kecakapan serta keterampilan tertentu pada peserta didik, namun lebih dari itu bahwa pendidikan menekankan aspek sikap dan pembentukan karakter yang baik. Undang-Undang Sistem Pendidikan Nasional dan sejumlah regulasi yang dikeluarkan Pemerintah telah mengindikasikan bahwa pendidikan perlu mengembangkan aspek sikap dalam membangun generasi muda yang cerdas yang penguasaan ilmu pengetahuan, santun dalam bertingkah laku, dan terampil serta tangguh dalam menghadapi segala tantangan kehidupan. Tulisan ini akan mengulas tentang pengembangan karakter melalui pendidikan agama Islam di Indonesia dan korelasinya dengan pembangunan mental dan spiritual anak bangsa.
\end{abstract}

Kata Kunci: Karakter, Pendidikan Agama Islam 


\section{A. Pendahuluan}

Pendidikan karakter mendapatkan perhatian serius akhir-akhir ini. Kementerian Pendidikan Nasional mengkampanyekan perlunya pengembangan pendidikan karakter bangsa. Sehingga mulai dari lembaga pendidikan tingkat dasar sampai pendidikan tinggi serentak menggalakkan pendidikan karakter. Padahal isu ini merupakan hal yang secara eksplisit telah lama dikaji oleh para filosof dimasa silam. Kajian mereka bahwa karakter bangsa adalah sesuatu bersifat kompleks, yang berlatar belakang pada sejarah, budaya dan agama dan keyakinan moral suatu bangsa.

Lalu mengapa pengembangan karakter bangsa menjadi salah satu program penting dan mendesak yang ingin digalkkan oleh pemerintah Indonesia saat ini. Menurut penulis, ada beberapa hal yang dapat diuraikan sebagai pemicu munculnya keinginan untuk mengedepankan karakter bangsa khususnya dalam pendidikan, yaitu :

1. Begitu banyaknya tindakan dan perilaku negative yang bertentangan dengan moral dan tidak mencerminkan identitas Indonesia sebagai Negara yang memiliki budaya sopan santun, seperti kebrutalan, perang antar etnis, suku, dan golongan tertentu dan kelompok agama.

2. Maraknya tindakan melawan hokum termasuk korupsi yang telah menjadi bagian dari kehidupan pemerintahan di Indonesia.

3. Peilaku pemuda, pelajar dan mahasiswa yang sering terlibat tawuran dan lebih mengedepankan kekerasan dalam menyelesaikan masalah.

4. Hilangnya tenggang rasa dan lebih mengedepankan kepentingan sendiri dan golongan disbanding kepentingan bersama.

Hal ini semakin menunjukkan adanya kesenjangan antara fungsi dan tujuan pendidikan yang tertuang dalam Undang-Undang Nomor 20 tahun 2003 tentang Sistem Pendidikan Nasional dengan realita yang terjadi di masyarakat. Dalam Undang-Undang Sistem Pendidikan Nasional telah dicantumkan bahwa: Pendidikan Nasional berfungsi mengembangkan kemampuan dan membentuk watak serta peradaban bangsa yang bermartabat dalam rangka mencerdaskan kehidupan bangsa, bertujuan untuk berkembangnya potensi peserta didik agar 
menjadi manusia yang beriman dan bertakwa kepada Tuhan Yang Maha Esa, berakhlak mulia, sehat, berilmu, cakap, kreatif, mandiri, dan menjadi warga Negara yang demokratis serta bertanggung jawab. ${ }^{1}$

Rumusan ini seakan mencerminkan bahwa karakter manusia Indonesia yang diinginkan terbentuk melalui pross pendidikan adalah manusia Indonesia yang beriman dan bertakwa kepada Tuhan Yang Maha Esa, berakhlak mulia, sehat, berilmu, cakap, kreatif, mandiri, dan menjadi warga Negara yang demokratis serta bertanggung jawab. Penekanan awal dalam tujuan ini seakan mencerminkan bahwa pendidikan di Indonesia sangat menekankan pada pembentukan manusia yang religious, yang memahami dan mengamalkan ajaran agama secara benar. Kemudian disusul dengan kemampuan keilmuan, kreatifitas, mandiri dan pada akhirnya menjadi warga Negara yang baik.

Jika karakter di atas telah tercermin dalam perilaku kehidupan masyarakat Indonesia, maka dengan demikian pengembangan karakter bangsa telah tercapai melalui proses pendidikan. Namun keadaan yang sebenarnya di masyarakat sangat berbeda, yang terjadi adalah hal-hal yang negative dan sama sekali belum menyentuh keseluruhan dari tujuan pendidikan. Bahkan pencapaian tujuan pendidikan di Indonesia masih bersifat parsial. Terbukti dengan munculnya orang yang memahami agama secara sempit dan kemudian tidak menjadi warga Negara yang baik, sehingga merusak tatanan nilai-nilai toleransi, menghormati dan menghargai antarsesama. Ada pula yang memahami ilmu pengetahuan, namun tidak memiliki landasan keagamaan yang baik sehingga cenderung menghalalkan segala cara.

Berdasarkan pada hal-hal tersebut, maka diperlukan adanya pengembangan karakter yang berlandaskan pada pendidikan agama Islam khususnya di lembaga pendidikan Islam. Sebab dalam Islam, pendidikan itu sangat penting. Dengan pendidikan yang benar dan berkualitas, individu-individu yang beradab akan terbentuk yang akhirnya memunculkan kehidupan sosial yang bermoral. Tentunya

${ }^{1}$ Direktorat Jenderal Pendidikan Islam Departemen Agama RI, Undang-Undang dan Peraturan Pemerintah RI tentang Pendidikan (Jakarta: Direktorat Jenderal Pendidikan Islam Departemen Agama RI, 2006), h. 8-9 
dengan memadukan Pendidikan agama Islam secara baik dan benar dan menerapkannya dengan baik dan benar dalam konteks keragaman di Indonesia.

Akan tetapi yang terjadi adalah banyak institusi pendidikan yang cenderung mementingkan penanaman kemampuan intelektual (kognitif) dan mengabaikan pentingnya kemampuan emosional dan spiritual (afektif). Sehingga yang muncul adalah siswa yang cerdas namun tidak memiliki nilai-nilai spiritual dan moral. Penekanan kepada pentingnya anak didik supaya hidup dengan nilai-nilai kebaikan, spiritual dan moralitas seperti terabaikan. Hal inilah yang sangat perlu diperbaiki dalam mengembangkan karakter bangsa.

\section{B. Pembahasan}

\section{Pengertian Karakter Bangsa}

Karakter memiliki makna keterlibatan seseorang dalam perbuatan atau perkataan yang berkaitan dengan moral atau kemampuan seseorang untuk menahan diri dari perbuatan atau perkataan tertentu. Selain itu karakter juga diartikan sebagai suatu perangkat komplek dari kualitas individual yang relative menetap dan pada umumnya mempunyai konotasi positif apabila digunakan dalam membahas masalah moral dan pendidikan moral.

Prof. Suyanto, PhD menjelaskan bahwa karakter adalah "cara berpikir dan berperilaku yang menjadi ciri khas setiap individu untuk hidup dan bekerjasama, baik dalam lingkup kehidupan keluarga, masyarakat, bangsa dan Negara". ${ }^{2}$ Lebih lanjut, Suyanto juga menyebutkan Sembilan pilar karakter yang berasal dari nilainilai luhur universal manusia, yang kelihatan sedikit berbeda dengan Sembilan pilar yang telah disebutkan di atas. Sembilan pilar karakter itu adalah:

1. Cinta Tuhan dan segenap ciptaan-Nya;

2. Kemandirian dan tanggung jawab;

3. Kejujuran/amanah;

4. Hormat dan santun;

5. Dermawan, suka tolong-menolong dan gotong royong/kerjasama;

6. Percaya diri dan pekerja keras;

\footnotetext{
${ }^{2}$ www.google.co.id/dikdasmen.
} 
7. Kepemimpinan dan keadilan;

8. Baik dan rendah hati, dan;

9. Toleransi, kedamaian, dan kesatuan.

Jumlah dan jenis pilar yang ingin dikembangkan dapat disesuaikan dengan kebutuhan dari daerah atau sekolah tertentu. Tergantung pilar mana yang menjadi poin penting yang harus segera di kembangkan di daerah atau sekolah tersebut. Jika dirasakan bahwa kejujuran mulai hilang dalam diri individu, maka nilai itulah yang dikedepankan dan seterusnya.

Menurut bahasa, karakter adalah tabiat atau kebiasaan. Sedangkan dalam pandangan psikologi, karakter adalah sebuah sistem keyakinan dan kebiasaan yang mengarahkan tindakan seorang individu. Karena itu, jika pengetahuan mengenai karakter seseorang itu dapat diketahui, maka dapat diketahui pula bagaimana individu tersebut akan bersikap untuk kondisi-kondisi tertentu. ${ }^{3}$

Unsur terpenting dalam pembentukan karakter adalah pikiran karena pikiran, yang di dalamnya terdapat seluruh program yang terbentuk dari pengalaman hidupnya, merupakan pelopor segalanya. ${ }^{4}$ Program ini kemudian membentuk sistem kepercayaan yang akhirnya dapat membentuk pola berpikirnya yang bisa mempengaruhi perilakunya. Jika program yang tertanam tersebut sesuai dengan prinsip-prinsip kebenaran universal, maka perilakunya berjalan selaras dengan hokum alam. Hasilnya, perilaku tersebut membawa ketenangan dan kebahagiaan. Sebaliknya, jika program tersebut tidak sesuai dengan prinsip-prinsip hokum universal, maka perilakunya membawa kerusakan dan menghasilkan penderitaan.

Jika kita melihat Tujuan Pendidikan Nasional yang tertuang dalam UUSPN No. 20 tahun 2003 terlihat bahwa karakter bangsa yang diinginkan dalam pendidikan nasional yaitu bertujuan pada berkembangnya potensi peserta didik agar menjadi manusia yang beriman dan bertakwa kepada Tuhan Yang Maha Esa, berakhlak mulia, sehat, berilmu, cakap, kreatif, mandiri, dan menjadi warga Negara yang demokratis serta bertanggung jawab.

\footnotetext{
${ }^{3}$ Singh, N.K. dan Agwan. A.R., Encyclopaedia of the Holy Qur'an, (New Delhi: Balaji Offest, 2000), h. 175

${ }^{4}$ R. Byrne, The Secret (Jakarta: PT Gramedia, 2007), h. 17
} 
Dalam pandangan penulis, tujuan awal 'manusia yang beriman dan bertakwa' merupakan landasan penciptaan lulusan dari suatu lembaga pendidikan. Apapun bidang ilmu yang ditekuninya harus didasari dengan agama dan menjadikan dirinya manusia beriman dan bertakwa. Tujuan berikutnya dapat dibagi ke dalam tiga ranah pendidikan, yaitu kognitif, afektif, dan psikomotor, yaitu :

a. Kognitif. Untuk memenuhi ranah kognitif maka Tujuan Pendidikan Nasional mengamahkan peserta didik menjadi orang yang sehat, berilmu dan cakap. Hal ini menunjukkan proses pendidikan harus mampu membekali peserta didik dengan ilmu pengetahuan yang memadai.

b. Afektif. Secara moral, ilmu perlu didasari dengan nilai dan norma yang berlaku. Tujuan ini penting untuk menciptakan generasi yang selaras antara kecerdasan intelektual dan emosional. Untuk mencapai keinginan ranah afektif maka dalam tujuan pendidikan nasional tercantum tujuan 'berakhlak mulia'.

c. Psikomotor. Secara fungsional, ilmu yang diperoleh harus dimanifestasikan dalam kehidupan sehari-hari dengan cara hidup dengan damai dan harmonis dalam perbedaan. Oleh karena itu, tujuan pendidikan nasional mencantumkan kata 'kreatif, mandiri, dan menjadi warga Negara yang demokratis serta bertanggung jawab' sebagai tujuan pendidikan.

Dengan demikian, dapat dikatakan bahwa inilah cermin dari karakter bangsa Indonesia yang diinginkan ada pada setiap manusia Indonesia setelah melalui proses pendidikan, yaitu yang menjadikan keimanan dan ketaqwaan kepada Tuhan sebagai landasan penting untuk membentuk insan yang berilmu dan warga Negara yang baik.

Tafsir menyatakan bahwa manusia yang beriman dan bertakwa kepada Tuhan harus menjadi core atau inti dari tujuan pendidikan nasional. ${ }^{5}$ Sehingga lulusan yang diharapkan merupakan lulusan manusia yang terbaik dengan dua ciri yaitu mampu hidup tenang dan produktif dalam kehidupan bersama. ${ }^{6}$ Di sinilah tersirat begitu pentingnya keberadaan Pendidikan Umum dengan pendidikan berbasis

${ }^{5}$ Tafsir, A. Filsafat Pendidikan Islami (Bnadung: Remaja Rosdakarya, 2008), h. 79

${ }^{6}$ Ibid., h. 156 
nilai dalam upaya menjawab 'tantangan' tujuan pendidikan untuk membangun karakter bangsa Indonesia.

\section{Pendidikan Agama Islam}

Pendidikan Agama Islam (PAI) merupakan usaha sadar untuk menyiapkan peserta didik dalam meyakini, memahami, menghayati, dan mengamalkan agama Islam melalui kegiatan bimbingan dan pengajaran atau latihan. ${ }^{7}$ Pendidikan Agama Islam merupakan basis penyangga kelanjutan ajaran agama Islam sepanjang sejarah kemunculan agama Islam. Nilai-nilai universal Islam hanya bisa diwariskan melalui proses pendidikan yang telah berlangsung sejak lama, dari masa Nabi Muhammad SAW, hingga kini dari generasi ke generasi berikutnya. Oleh karena itu berbagai metode dan strategi pembelajaran sudah banyak diterapkan guna mempertahankan keberlangsungan ajaran agama Islam itu sendiri melalui proses pendidikan.

Pendidikan tidak hanya diarahkan untuk melahirkan individu-individu pragmatis yang bekerja untuk meraih kesuksesan materi dan profesi sosial yang akan memakmuran diri dan kelompoknya. Pendidikan tidak bisa dipandang hanya secara ekonomis dan dianggap sebagai sebuah investasi yang menggiurkan dari segi materi. Pendidikan seharusnya menjadi suatu proses untuk menjadikan manusia yang bermakna dalam arti beriman dan bertaqwa kepada Tuhan dan mengimplementasikan semua kemampuan yang dimilikinya kepada kemaslahatan umat dan kehidupan bersama dalam masyarakat. Hal ini sejalan dengan pendapat Al Syaebani dalam Arifin (2000: 14) menjelaskan bahwa pendidikan Islam merupakan sebuah usaha mengubah tingkah laku individu dalam kehidupan pribadinya atau kehidupan kemasyarakatannya dan kehidupan dalam alam sekitarnya melalui proses pendidikan. ${ }^{8}$

Hal itu penting untuk dikaji karena sistem pendidikan yang hanya menitikberatkan pada intelektual tanpa mementingkan aspek sikap dan karakter yang baik, sekalipun akan memproduksi anak didik yang memiliki status

${ }^{7}$ A.R. Saleh, Pendidikan Agama dan Keagamaan (Jakarta: Gema Windu Panca Perkasa, 2000), h. 427

${ }^{8}$ Arifin, H.M. Filsafat Pendidikan Islam (Jakarta: PT. Bumi Aksara, 2000), h. 14 
pendidikan yang tinggi, namun status tersebut tidak akan menjadikan mereka sebagai individu-individu yang beradab. Pendidikan yang bertujuan pragmatis dan ekonomis sebenarnya merupakan pengaruh dari paradigm pendidikan yang sekular.

Dalam pendidikan sekular, tingginya pendidikan seseorang tidak berkorespondensi dengan kebaikan dan kebahagiaan individu yang bersangkutan. Masih ada kesenjangan antara tingginya pendidikan yang diraih dengan rendahnya moral serta akhlak kehidupan Muslim. Ini terjadi disebabkan visi dan misi pendidikan yang pragmatis. Sebenarnya, agama Islam memiliki tujuan yang lebih komprehensif dan integratif disbanding dengan sistem pendidikan sekular yang semata-mata menghasilkan para anak didik yang memiliki paradigm yang pragmatis.

Pendidikan Islam selalu mengedepankan konsep pendidikan yang bernuansa aplikatif dalam menciptakan masyarakat yang beradab dan memiliki karakter yang baik

\section{Pengembangan Karakter dalam Pendidikan Islam}

Kondisi saat ini dalam dunia pendidikan di Indonesia sangatlah memerlukan perhatian lebih pada pengembangan potensi siswa secara menyeluruh dan tidak hanya pada penciptaan siswa yang berfungsi sebagai pekerja yang hanya memiliki kemampuan berpikir statis yang mengedepankan aspek intelektual dan mengabaikan aspek emosional dan spiritual. Dengan demikian penekanan proses pendidikan harus diarahkan pada sebuah proses penciptaan manusia yang mampu memberikan kontribusi berharga dalam kehidupan dengan kemampuan pengetahuan, sikap dan keterampilan yang dimilikinya.

Dalam konteks pendidikan Islam, siswa harus diarahkan untuk memahami nilai-nilai mulai dalam Islam dan kemudian manfaat yang dapat mereka peroleh setelah melaksanakan nilai-nilai tersebut. Sebagai contoh, dalam pembelajaran materi shalat, seorang guru dapat menjelaskan nilai-nilai yang terkandung didalamnya, seperti : 


\section{a. Kejujuran (Honesty)}

Seseorang yang melaksanakan sholat harus mampu berlaku jujur dalam sholatnya. Yaitu dalam hal jumlah rakaat yang dikerjakan. Sehingga meskipun sedang melaksanakan sholat sendiri, siswa tidak akan pernah mengurangi jumlah rakaat sholatnya kecuali ketika mengqashar. Yang perlu ditanamkan juga mengapa hal ini perlu dilakukan karena Allah senantiasa melihat dan memperhatikan setiap hambaNya. Manfaatnya, selain dia melaksanakan tuntutan agama dan memupuk salah satu sikap baik, sesungguhnya orang yang selalu jujur sedang mendekatkan diri pada Allah.

\section{b. Tanggung jawab (responsibility)}

Sholat merupakan tanggung jawab setiap manusia kepada Allah. Oleh karena itu, setiap siswa dianjurkan untuk sholat tanpa harus diperintah karena setiap manusia akan diminta pertanggungjawabannya atas semua amal perbuatannya.

\section{c. Disiplin}

Melalui sholat, siswa dilatih untuk disiplin waktu. Ketika masuk waktu sholat maka segera melaksanakan sholat.

\section{d. Kerja sama (cooperative)}

Sholat juga mengajarkan kerja sama antara Imam dan ma'mum. Kerja sama ini tidak hanya berlaku dalam sholat saja, akan tetapi sebuah pencerminan perilaku ketika berada di masyarakat.

\section{e. Adil (fairness)}

Prinsip keadilan tercermin dari shaf-shaf dalam sholat. Siapa yang datang lebih awal dapat menempati shaf terdepan dan bagi yang belakangan berada di belakang. Islam mengajarkan keadilan melalui sholat berjamaah.

\section{f. Peduli (caring)}

Gerakan pada akhir sholat, mencerminkan kepedulian pada sama. Ketika mengucapkan salam dan menoleh ke kiri dan ke kanan adalah sebuah pencerminan nilai kepedulian terhadap sesama.

Nilai-nilai di atas adalah sebagian dari karakter yang dapat dibentuk dari pelaksanaan sholat, sehingga Ari Ginanjar Agustian menjadikan sholat sebagai 
cara untuk membentuk karakter (character building). ${ }^{9}$ Ary Ginanjar Agustian juga menyebut bahwa sholat memberikan manfaat dari sinergi yang luar biasa pada para pelakunya. Mulai dari isi sholat itu sendiri, seperti shalawat, salam, kerapian shaf, sistem imam dan ma'mum, kesatuan dan kesamaan gerakan, kesamaan visi dam misi dalam sholat, saling mendoakan, bahkan cara memperbaiki imam apabila melakukan kesalahan, sungguh merupakan contoh sinergi yang terbaik. ${ }^{10}$

Oleh karena itu, jika nilai-nilai dalam sholat dapat diterapkan dalam kehidupan sehari-hari, maka diharapkan dapat membentuk karakter yang baik bagi para pelakunya, khususnya para siswa melalui pembelajaran agama Islam di sekolah.

Demikian pula dalam materi lain seperti puasa yang memberikan penanman nilai pengendalian diri (self controlling), zakat yang memberikan nilai kepedulian pada sesama (caring) dan haji yang merupakan perwujudan dari aksi totalitas (total action) manusia untuk beribadah kepada Allah SWT.

Dalam melaksanakan program pembelajaran yang berlandaskan pada pengembangan karakter perlu memperhatikan tata cara yang baik, diantaranya:

\section{Komunikasi untuk menyuruh pada kebaikan dan mencegah keburukan}

\section{(Amar Ma'ruf Nahi Munkar)}

Menurut Hawari (Sauri, 2009: 3), perilaku-perilaku menyimpang yang dilakukan anak-anak yang sering terjadi disebabkan karena tidak adanya komunikasi yang lebih baik antara keluarga, sekolah dan masyarakat. Faktor tidak adanya komunikasi menjadi titik sentral dalam pandang Hawari. Hal ini menyiratkan perlu adanya komunikasi untuk menjembatani segala perbedaan pola piker dan cara pandang terhadap sesuatu. ${ }^{11}$

Oleh karena itu, sebagai antara guru memiliki tugas amar ma'ruf nahi munkar kepada siswanya untuk mencegah kemukaran dan menyuruh pada kebaikan melalui komunikasi. Al-Qur'an mengisyaratkan:

${ }^{9}$ Agustian, A.G. ESQ: Rahasia Sukses Membangun Kecerdasan (Jakarta: Arga, 2005), h.

${ }^{10}$ Ibid., h. 227

${ }^{11}$ Sofyan Sauri, "Menuju Tenaga Guru Profesional" Makalah pada Wisuda Sarjana Strata Satu dan Program Diploma STAIS Lantaboer, Jakarta. 2009, h. 7 
"Dan orang-orang beriman, lelaki dan perempuan, sebahagian mereka adalah menjadi penolong bagi sebagian lain. Mereka menyuruh mengerjakan yang baik dan mencegah dari yang buruk, mendirikan shalat, menunaikan zakat, dan mereka taat kepada Allah dan Rasul-Nya. Mereka itu akan diberi rahmat oleh Allah. Sesungguhnya Allah Maha Perkasa lagi Maha Bijaksana.” (QS. At-Taubah: 71)

\section{Nasehat dan cara yang baik (bil hikmah wal mauizhatil hasanah)}

Untuk melaksanakan pengembangan karakter yang baik dalam diri siswa, Islam telah memberikan tuntunan yaitu tidak bisa terlepas dari misi Islam sebagai rahmatan lil'alamin. Misi itulah yang mendorong Rasulullah untuk menyampaikan da'wah dengan penuh kasih sayang. Allah berfirman, "Dan tidaklah kami mengutus kamu, melainkan untuk menjadi rahmat bagi semesta alam" atau dalam Q.S An Nahl: 125 Allah SWT memberikan pedoman untuk mengajak manusia ke jalan Allah dengan cara-cara yang bil hikmah wal mau'izatil hasanah (dengan hikmah dan cara-cara yang santun lagi baik).

Kidder dalam Majid dan Andayani, menyampaikan tujuh kualitas yang diperlukan dalam pendidikan karakter, yaitu Seven E's (Empowered, Effective, Extended in to the community, Embedded, Engaged, Epistemological, Evaluative).

1. Empowered (pemberdayaan). Pendidik harus mampu memberdayakan dirinya untuk memberikan pendidikan karakter dengan dimulai dari diri sendiri.

2. Effective, proses pendidikan harus dilaksanakan dengan efektif dalam arti berhasil dan bermanfaat sesuai dengan harapan.

3. Extended into the community, komunitas harus membantu dan mendukung sekolah dalam menanmkan nilai-nilai.

4. Embedded, mengintegrasikan seluruh nilai ke dalam kurikulum dan seluruh rangkaian proses pembelajaran.

5. Engaged, melibatkan komunitas dan menampilkan topik-topik yang esensial.

6. Epistemological, harus ada koherensi antara cara berpikir makna etik dengan upaya yang dilakukan untuk membantu peserta didik menerapkannya secara benar. 
7. Evaluative, menilai sikap peserta didik dalam aktifitasnya setelah memahami dan menghayati suatu nilai. ${ }^{12}$

Dalam pelaksanaannya, Brooks dan Gooble dalam (Elmubarok, 2008: 112) memberikan pedoman yang perlu diperhatikan yaitu, prinsip, proses, dan prakteknya. Dalam menjalankan prinsip itu, maka nilai-nilai harus termanifestasikan dalam semua aktifitas. Sehingga mulai dari proses pembinaan sudah terlihat contoh teladan untuk penanaman nilai. Prinsip mencakup kegiatan pemahaman dan pemaknaan akan nilai-nilai, kemudian memasuki proses penerimaan nilai dan aplikasi dalam kehidupan. ${ }^{13}$

\section{Kesimpulan}

Berdasarkan pembahasan di atas dapat disimpulkan beberpa hal sebagai berikut :

1. Pengembangan karakter bangsa dalam pendidikan berpedoman pada tujuan pendidikan nasional yang tertuang dalam Undang-Undang Nomor 20 tahun 2003 yaitu untuk berkembangnya potensi peserta didik agar menjadi manusia yang beriman dan bertakwa kepada Tuhan Yang Maha Esa, berakhlak mulia, sehat, berilmu, cakap, kreatif, mandiri, dan menjadi warga Negara yang demokratis serta bertanggung jawab. Dengan demikian karakter bangsa yanag diinginkan dalam pendidikan adalah yang berdasarkan pada Undang-Undang tersebut.

2. Pengembangan karakter bangsa yanag berlandaskan pendidikan Islam dapat dilaksanakan dengan menjelaskan makna dan nilai-nilai yang diperoleh dari pembelajaran pada setiap materi pendidikan agama Islam agar siswa dapat memahami dan melaksanakan dalam kehidupan seharihari.

3. Upaya pengembangan karakter melalui pendidikan agama Islam dapat dilakukan dengan komunikasi yang baik memberikan anjuran kebaikan

\footnotetext{
${ }^{12}$ A. Majid, dan Andayani, D. Pendidikan Karakter dalam Perspektif Islam (Bandung: Insan Cita Utama, 2010), h. 36-37

${ }^{13}$ Z. Elmubarok, Memberikan Pendidikan Nilai (Bnadung: Alfabeta, 2008), h. 112
} 
dan mencegah kemunkaran serta menyampaikan nasihat yang baik, melalui contoh teladan dan penanaman nilai dalam aktifitas sehari-hari. 


\section{$\underline{\text { Daftar Pustaka }}$}

Al Quran Al Karim

Agustian, A.G. (2005). Rahasia Sukses Membangun Kecerdasan. Jakarta: Arga.

Arifin, H.M. (2000), Filsafat Pendidikan Islam, Jakarta: PT. Bumi Aksara.

Byrne, R. (2007), The Secret, Jakarta: PT Gramedia.

Republik Indonesia, Undang-Undang Nomor 20 Tahun 2003 tentang Sistem Pendidikan Nasional.

Saleh, A.R, (2000), Pendidikan Agama dan Keagamaan, Jakarta: Gema Windu Panca Perkasa.

Sauri, S (2009), "Menuju Tenaga Guru Profesional”. Makalah pada Wisuda Sarjana Strata Satu dan Program Diploma STAIS Lantaboer, Jakarta.

Singh, N.K dan Agwan, A.R, (2000), Encyclopaedia of the Holy Qur'an, New Delhi: Balaji Offset.

Tafsir, A. (2008). Filsafat Pendidikan Islami. Bandung: Remaja Rosdakarya.

Wynne, E., \& Walberg, H. (Eds). (1984). Developing character: Transmitting knowledge. Posen, IL: ARL.

Elmubarok, Z. (2008). Membumikan Pendidikan Nilai. Bandung: Alfabeta.

Majid, A. dan Andayani, D. (2010). Pendidikan Karakter dalam Perspektif Islam. Bandung: Insan Cita Utama.

www.google.co.id 